\title{
The earliest Pleistocene archaeological sites in western Iberia: Present evidence and research prospects
}

\author{
Luiz Oosterbeek $^{\mathrm{a}}$, Stefano Grimaldi ${ }^{\mathrm{b}, *}$, Pierluigi Rosina ${ }^{\mathrm{a}}$, Sara Cura ${ }^{\mathrm{c}}$, Pedro P. Cunha ${ }^{\mathrm{d}}$, António Martins ${ }^{\mathrm{e}}$ \\ ${ }^{a}$ Department of Landscape, Archaelogy and Heritage, Instituto Politécnico de Tomar, Portugal \\ ${ }^{\mathrm{b}}$ Department of Phylosophy, History, Heritage, Trento University, Italy \\ ${ }^{\mathrm{c}}$ Museu de Arte Pré-Histórica de Mação, Portugal \\ ${ }^{\mathrm{d}}$ Department of Earth Sciences, IMAR-Marine and Environmental Research Centre, University of Coimbra, Portugal \\ ${ }^{\mathrm{e}}$ Department of Earth Sciences, Geophysics Centre, University of Évora, Portugal
}

\section{A R T I C L E I N F O}

Article history:

Available online 2 February 2010

\begin{abstract}
A B S T R A C T
Archaeological evidence for the earliest human presence in western Iberia is summarised and discussed. Western Iberia is geologically characterised by magmatic and metamorphic rocks (Hesperian Massif) but also by siliciclastic and carbonate Mesozoic and Cenozoic formations. The geological context affects the distribution of Pleistocene archaeological sites, as the most of the archaeological evidence known today is located in river terrace formations or in karst deposits. Very few sites have been fully investigated; the older ones are tentatively dated as middle/late Middle Pleistocene. Recent results have been obtained using an archaeological and geomorphological approach carried out in the Portuguese region of Alto Ribatejo. Dating of the lithic assemblages found in fluvial terraces or in cave deposits indicates that the first human presence in Portugal is not older than the OIS 8-9. However, it remains difficult to explain the long chronological gap between the archaeological evidences in western Iberia and the older sites in central and eastern Iberia, such as those in the Sierra de Atapuerca and Guadix Baxa areas.
\end{abstract}

(c) 2010 Elsevier Ltd and INQUA. All rights reserved.

\section{Introduction to the earliest archaeological contexts in western Iberia}

The Iberian Peninsula presents a significant diversity in the geological structure and, consequently, in geomorphological features. The Hesperian Massif, formed by Palaeozoic and Pre-Cambric metasediments and igneous rocks, dominates central Iberia, whereas the western and southern borders consist of Mesozoic and Cenozoic sedimentary successions, mainly siliciclastics and limestones (Fig. 1).

The Iberian fluvial network comprises five main rivers: Tejo (Tajo), Douro (Duero), Guadiana, Ebro and Guadalquivir. Only the Ebro drains to the Mediterranean Sea. The Tejo and the Douro rivers have their mouths on the western Atlantic coast, and the Guadiana and Guadalquivir rivers in the southern coast (Fig. 1).

Most of the archaeological evidence known today is located in river terraces or in karst deposits. Studies of the evidence, notably lithic assemblages, have been carried out since the end of the 19th century (Ribeiro, 1871; Cabral, 1881; Serpa Pinto, 1932) and

\footnotetext{
* Corresponding author.

E-mail address: stefano.grimaldi@unitn.it (S. Grimaldi).
}

considerably increased after the 1940s (e.g. Breuil and Zbyszewski, 1942, 1945; Ribeiro, 1943; Zbyszewski, 1943, 1946, 1953, 1958; Breuil, 1959). The typological approach, the influence of Biberson (1961a, 1961b, 1976), on the concept of northern African Pre-Acheulean complexes, and the "Gibraltar Strait hypothesis" as being the "gateway" from Africa to Europe in earlier times (Penalva, 1978), led several authors to suggest a Lower Pleistocene human presence in western Iberia, witnessed by the "Pebble Industries" of the Portuguese littoral (Azevedo et al., 1979; Penalva, 1980; Raposo, 1985; Raposo and Carreira, 1986; Raposo and Santonja, 1996) as well as by some sites in western Spain (e.g. El Aculadero) (Querol and Santonja, 1983).

Although a Lower Pleistocene occupation of the Iberia peninsula is well documented in several contexts, particularly those related with the Sierra de Atapuerca and Guadix-Baza regions (Carbonell et al., 2008), the Western Iberia lithic industries, most located in Portugal and tentatively attributed to a very ancient human presence, are characterised mainly by surface assemblages. These artefacts usually show different patinas, a undefinable mixture of typological features, and have been tentatively dated relative to the age of the geological formation situated below, ages of which are not always well constrained (e.g. Penalva, 1978, 1980; Azevedo et al., 1979; Cardoso and Penalva, 1979; Zbyszewski et al., 1979, 1981, 1982). 


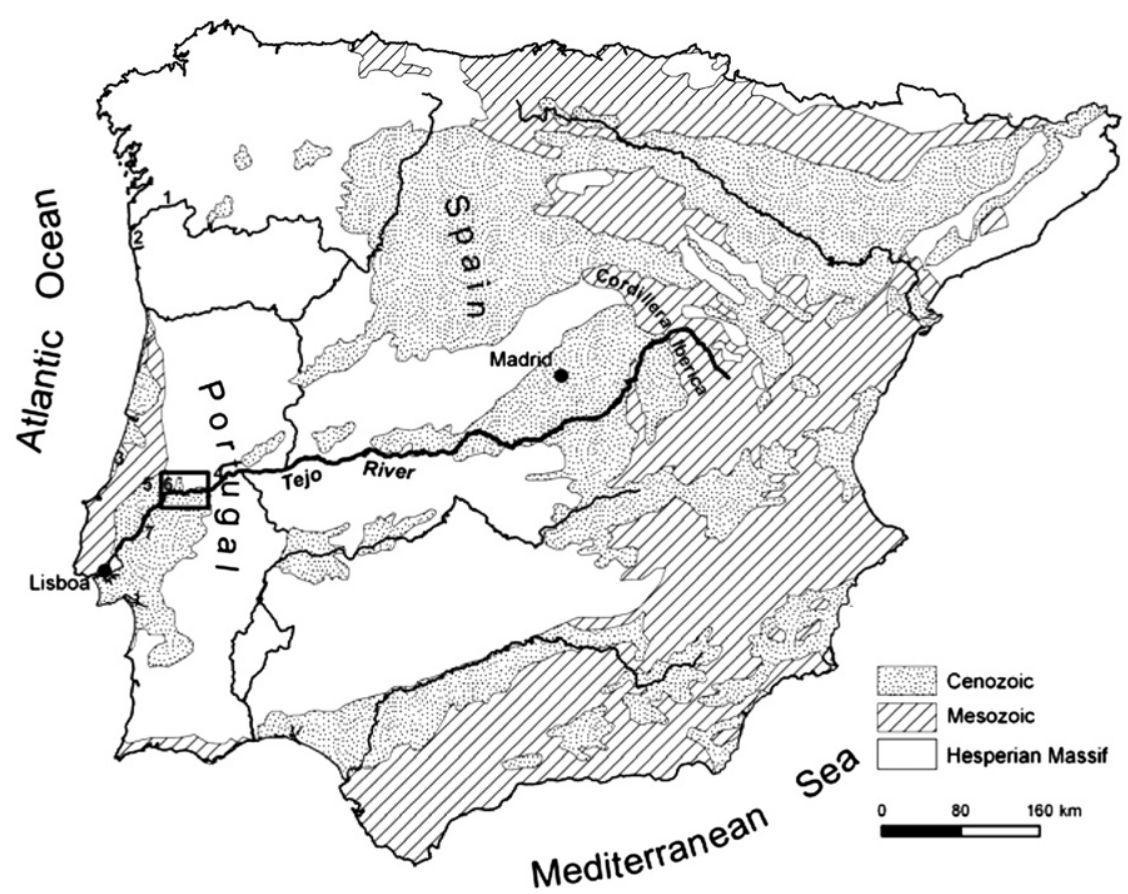

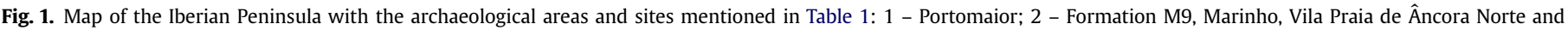

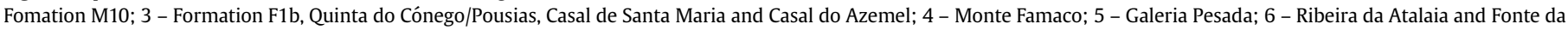
Moita; 7 - Vale do Forno 3/Milharós and Vale do Forno 8.

To date, very few sites have been investigated using an integrated geoarchaeological approach. The most ancient ones have been tentatively dated as middle/late Middle Pleistocene following mainly typological attributions of lithic implements (e.g. Cunha Ribeiro et al., 1989; Cunha-Ribeiro, 1990, 1993, 1996-1997, 2002; Raposo, 1993; Raposo et al., 1993).

The studies performed at the archaeological sites located in the "middle" terrace of the Tejo River, near the Alpiarça village, are an example of research based on the typology of the lithic implements combined with geomorphologic studies. In the Vale do Forno and Vale da Atela (Fig. 1), within the two main sedimentary units of the middle terrace of the Tejo River, the Lower Gravels and the Upper Sands, several sites have been excavated and subject to detailed studies, including TL dating (Mozzi et al., 2000). Artefacts related with the Lower Gravels unit are scarce and essentially result from surface surveys. The sites associated with the Upper Sands unit, however, are more relevant, namely the sites of Vale do Forno 1, 3 and 8. The VF1 lithic implements consist of a not very evolved Acheulean type (Middle Acheulean). Preliminary typological analysis shows "a high percentage of flaked pebbles, unifacial choppers, and hand axes, commonly of quite rough manufacture, with many fewer implements on flakes" (Mozzi et al., 2000, p. 364). The VF8 excavation revealed an assemblage of around 3000 artefacts which have not been extensively published, but are described as "an Upper Acheulian industry with many tools on flakes and bifaces with good flaking technique" (Mozzi et al., 2000, p. 365). Finally, the lithic assemblage from the VF3, also known as Milharós (Raposo et al., 1985; Raposo et al., 1993; Raposo, 2002), is considered as a Late Acheulian of Micoquian type, this cultural attribution based on the typological features of some lanceloate and micoquian bifaces (Mozzi et al., 2000, p. 365) (Fig. 2).

In summary, following typological criteria, the lithic industries of the sites are considered as representative of a Palaeolithic cultural sequence ranging from Middle Acheulian to Micoquian (Mozzi et al., 2000, p. 365). According to the geomorphologic studies of Mozzi et al. (2000), the cultural sequence matches the different stratigraphic positions of the sites in the alluvial series. Even if the TL ages are not entirely reliable $(119+\infty /-32 \mathrm{ka}$ correlated with the Micoquian assemblages and $127+\infty /-26 \mathrm{ka}$ for the Middle Acheulian ones) the same authors consider that the dates, "support the archaeological arguments for last interglacial/ early phases of the last glacial ages for the VF1, VF8, and VF3 lithic industries and for the U.S. deposits that contain them" (Mozzi et al., 2000, p. 369).

Also in the Tejo valley, but in the region of Vila Velha de Rodão (Fig. 1) detailed geomorphologic studies have been recently published which provide a more precise age for the archaeological materials of the Monte Famaco site, recently considered to represent the T4 terrace of a suite of six terraces identified at the Lower Tejo Basin and dated (IRSL) as $\geq 280-136 \mathrm{ka}$ (Cunha et al., 2008; Martins et al., 2009). At the Monte do Famaco site (GEPP, 1977; Raposo, 1987, 1993), two series of lithic industries were identified. One comes from the T4 terrace which is made up of a $1-\mathrm{m}$ thick clast-supported gravel-boulder conglomerate, with poor sorting (Cunha et al., 2008). The assemblage is composed of thirty-four worn out quartzite implements tentatively "attributed to the early middle Acheulean (Lower Palaeolithic)” (Raposo, 1987; Cunha et al., 2008, p. 47). The second series of 1500 implements was collected in colluvium at the top of the terrace. Though never extensively published, this assemblage includes, among other lithic morphologies, a high quantity of bifaces and cleavers (Raposo et al., 1993) (Fig, 2).

In the north of Portugal, especially in the littoral between Póvoa de Varzim and Caminha and in the Minho River (Fig. 1), despite the generalised absence of numerical dating, several studies have been done aiming at the establishment of a lithostratigraphic sequence for the Quaternary deposits as well as clarification of its relationship with lithic industries (Texier and Meireles, 1987; Meireles, 1992). These regional studies pointed to the existence of a first human occupation chronologically situated between 250 and 200 ka and related to the MIS 7 (Meireles, 1994, p. 32). The Acheulian cultural attribution of these most ancient assemblages is not 

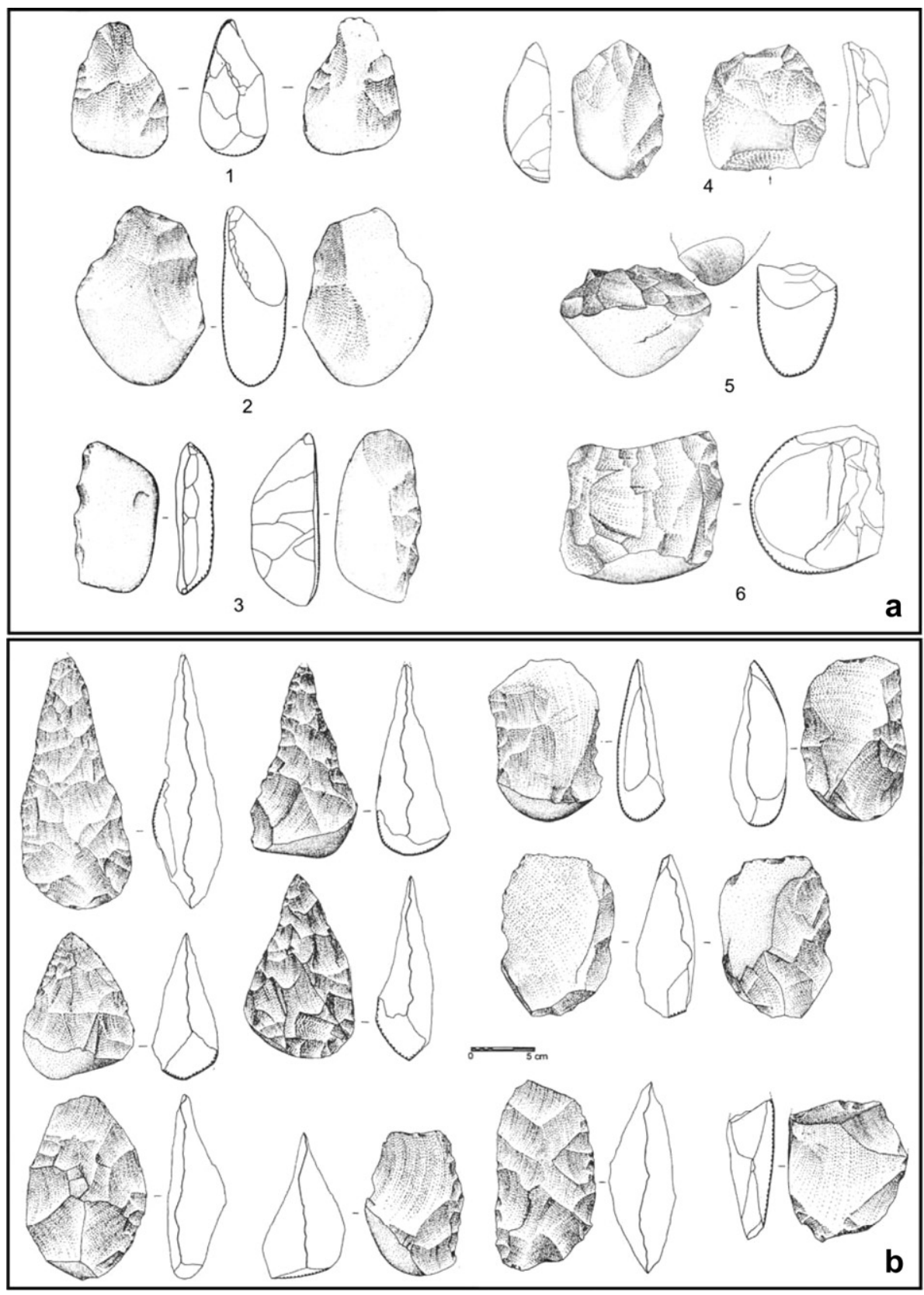

Fig. 2. Lithic implements from Monte Famaco site (a): 1-3 - worn out series, 4-6 s serie; and Vale do Forno 3 (b) (after Raposo 1993, 2002).

entirely admitted by the author, who underlines the peculiar techno-typological features of the lithic industries in this region, from the late middle Pleistocene into the Holocene, essentially dominated by unifacial tools and unifacial flaking methods, with a substantial presence of worked pebbles (Fig. 3).

The recent discovery of the Portomaior site (Mendez Quintas et al., 2006), adds relevant information to the earliest human occupation of the Minho River due to its clear in situ morphostratigraphic position. Portomaior is located in the middle terrace ( +30 to $40 \mathrm{~m}$ ) of the Minho River. Four different stratigraphic levels revealed a lithic assemblage considered as Acheulian. Although in the Portuguese northern Atlantic coast bifaces and cleavers are almost absent, here they are well represented (Méndez Quintas et al., 2006, p. 188). Despite of the absence of numerical dating and faunal remains, the relative position of the terrace allows its attribution to the second half of the Middle Pleistocene. The discovery of the Portomaior site is relevant considering that earlier efforts focused on the problematic stratigraphic sequence of the Gandaras de Bundiño site in the same valley, remain rather inconclusive (Gracia Prieto et al., 2004).

In the coastal zone of central Portugal (Fig. 1) studies done at the Lis River (Cunha-Ribeiro, 1992-1993, 1996, 1999) identified three human occupation stages, associated with Pleistocene fluvial and colluvial deposits, but no numerical dating is available. Nevertheless, the study of the lithic assemblages allowed the characterization of the Acheulean industries' evolution, based on typological criteria, and on their technological features as well: raw material, economy and landscape occupation (Cunha-Ribeiro, 2002).

The available data can be summarised as follows (CunhaRibeiro, 2005). 

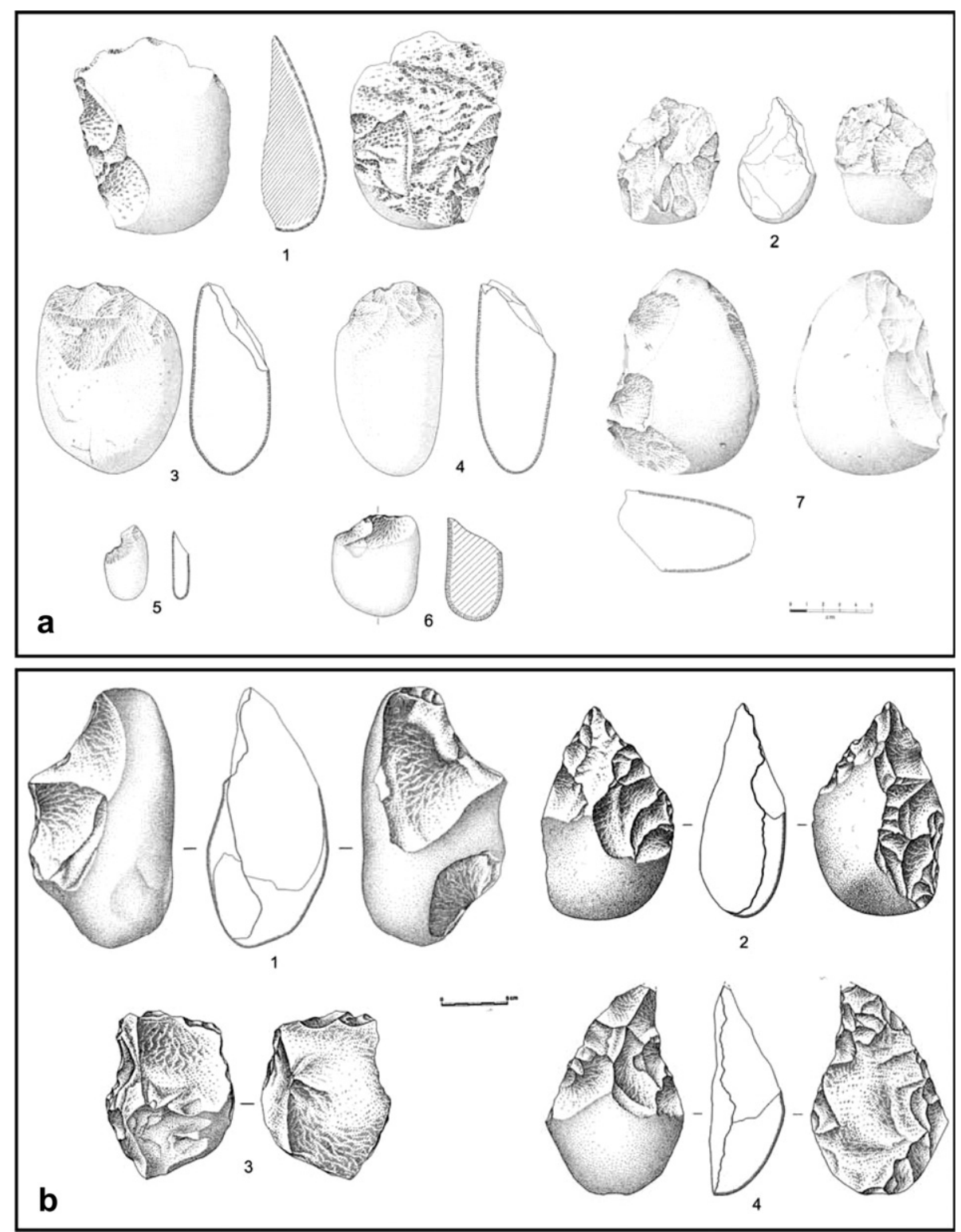

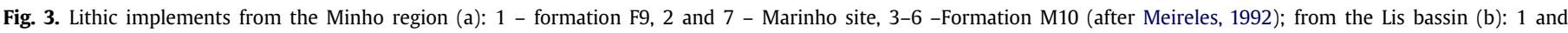
2 - Formation F1, 3 - Quinta do Cónego/Pousias, 4 - Casal do Azemel (after Cunha-Ribeiro, 2005).

- The earliest remains are associated with the F1 fluvial formations (Fig. 3) and consist of scattered materials found at the base of sandy deposits. The Pousia/Quinta do Cónego site is also associated with the same formations, but has a higher concentration of artefacts. These are considered to be representative of Acheulian industries. Detailed descriptions are reported in Cunha-Ribeiro (1999).

- A second instance shows a diverse territorial occupation pattern, but the lithic assemblages are quite similar.

- A significant difference appears in the third instance of human occupation, particularly represented in the lithic assemblage of the Casal do Azemel site. Here, although elements such as hand axes and cleavers show a relation with the Acheulean industries, the extensive presence of plano-convex bifacial tools (Fig. $3, n^{\circ} 4$ ) and the centripetal reduction sequence is closer to the Middle Palaeolithic (Cunha-Ribeiro, 1995, 2000).

An exception to the open air/fluvial contexts is the Galeria Pesada Cave (Fig. 1). This cave belongs to the Almonda karst system and is located in a south-facing cliff, near Torres Novas town in the Portuguese Estremadura region. The excavation of this site started in the early 1990s and the currently published data indicate the existence of a series of geological units within the brecciated deposits (Marks et al., 1999, 2002a, 2002b). These units present five stratigraphic layers that yielded a dense quantity of lithic and bone remains. The abundant faunal assemblage records species that suggest a Middle Pleistocene age for the Galeria Pesada deposits, indicated by the presence of Corvus cf. antecorax, which became extinct at the end of the Middle Pleistocene. The numerical dates of a Equus aff. and Mosbachensis tooth which provided an ESR date of $241+30 /-22$ ka corroborate the Middle Pleistocene age. The bone record of this site contains the most ancient human remains so far identified in the Iberian Atlantic coast. Two archaic human teeth, a mandibular canine and a maxillary third molar, have been recovered and considered has being similar to those of other Middle Pleistocene European humans, though no more precise identification on a species level has been accomplished (Trinkaus et al., 2003). The lithic assemblage of Galeria Pesada, essentially 


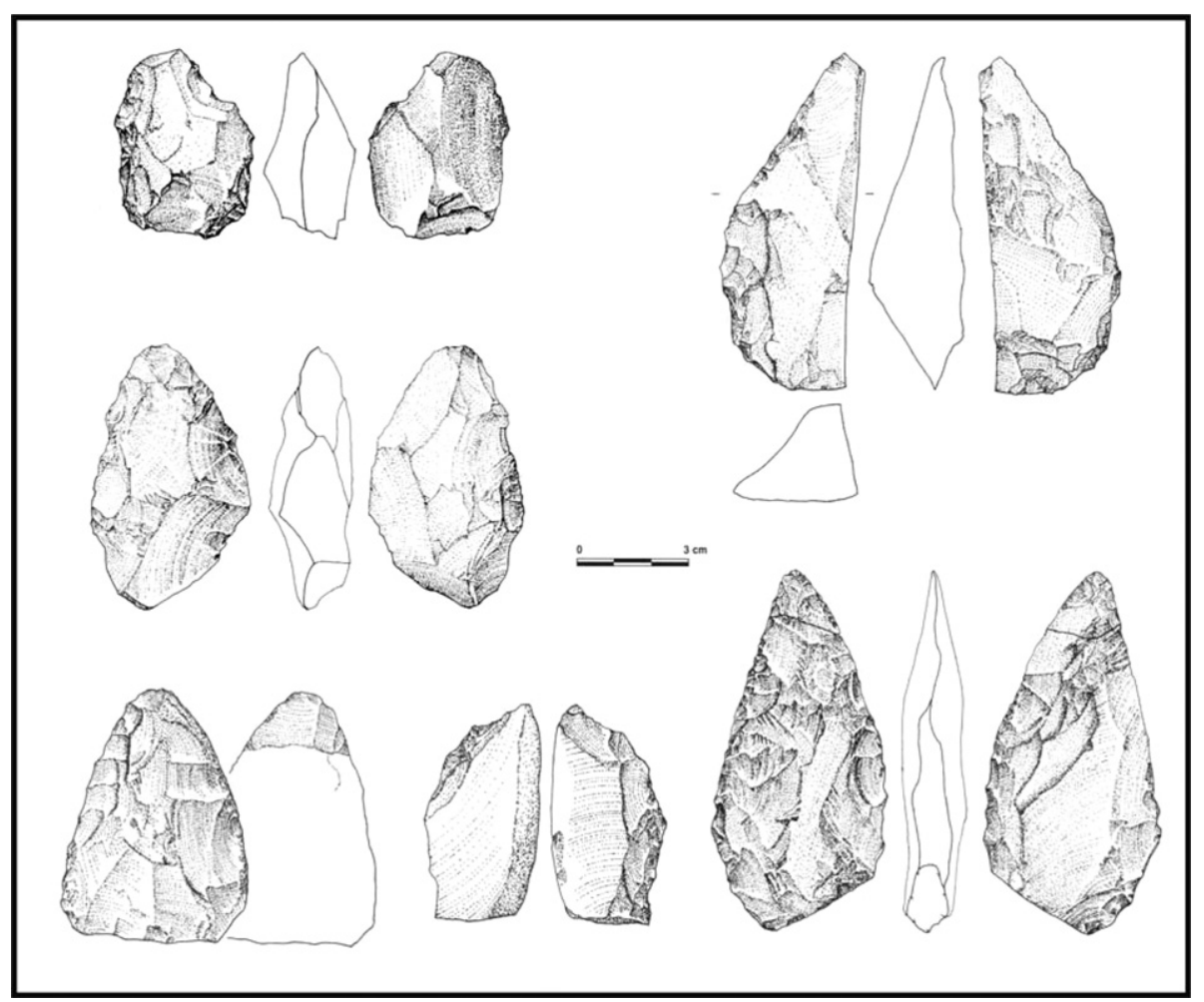

Fig. 4. Lithic implements from the Galeria Pesada cave (after Marks et al., 2002a, 2000b).

made on local raw materials (quartzite, quartz, flint and limestone) contains some implements considered as typical Acheulian. The Levallois method is present, but not as extensively as the discoid one, but the authors underline the important component of small asymmetric bifacial tools, partly bifacial tools (points) and bifacial retouched knives, that are, from a morphological point of view, typical of the Micoquian (Keilmessergruppe) of central Europe (Marks, 2005) (Fig. 4). Despite the striking morphological resemblance, the author himself states that "while it may be tempting to proclaim possible connection, such seem highly unlikely (...) Within Iberia, there are simply no comparable assemblages of any age. At the moment, the Galeria Pesada assemblages stand alone, typologically and technologically" (Marks et al., 2002a, 2000b, p. 24). According to the extensive cut marks and other modifications found on faunal bones, extensive butchering and defleshing took place in the site; the assemblages may represent the material remains of, if not base camps, than of camp sites where a range of activities took place.

\section{New evidence from the Alto Ribatejo (central Portugal)}

Apart from the cave deposits, such as Galeria Pesada, the fluvial sequences of the Tejo River offer wide possibilities for dating, as they provide biostratigraphical data that can be compared with

Table 1

Main features of the earliest archaeological contexts of western Iberia.

\begin{tabular}{|c|c|c|c|c|}
\hline Area & Site & Geomorphological context & Age & $\begin{array}{l}\text { Lithic implements } \\
\text { (bifaces + cleavers) }\end{array}$ \\
\hline Minho & $\begin{array}{l}\text { Portomaior } \\
\text { Formation M9 } \\
\text { Marinho } \\
\text { Vila Praia de Âncora Norte } \\
\text { Formation M10 }\end{array}$ & $\begin{array}{l}\text { Fluvial terrace } \\
\text { Coastal terrace } \\
\text { Colluvium } \\
\text { Coastal terrace }\end{array}$ & & $\begin{array}{l}130(48+10) \\
19(0+2) \\
612(10+3) \\
160(0+0) \\
140(0+0)\end{array}$ \\
\hline Lis & $\begin{array}{l}\text { Formations F1b } \\
\text { Qta Cónego/Pousias } \\
\text { Casal de Santa Maria } \\
\text { Casal do Azemel }\end{array}$ & $\begin{array}{l}\text { Fluvial terrace } \\
\text { Fluvial terrace } \\
\text { Colluvium } \\
\text { Colluvium }\end{array}$ & & $\begin{array}{c}457(59+10) \\
974(89+42) \\
336(8+20) \\
3432(556+127)\end{array}$ \\
\hline Vila Velha de Ródão & Monte do Famaco & $\begin{array}{l}\text { Surface in association with } \\
\text { the Tejo T4 fluvial terrace }\end{array}$ & $\sim 280$ to $136 \mathrm{ka}$ (IRSL) for the T4 terrace & $34(4+1) 1500$ \\
\hline Alto Ribatejo & $\begin{array}{l}\text { Galeira Pesada } \\
\text { Rib. da Ponte da Pedra } \\
\text { Fonte da Moita }\end{array}$ & $\begin{array}{l}\text { Karst cave } \\
\text { Base of the T4 fluvial terrace } \\
\text { T4 fluvial terrace }\end{array}$ & $\begin{array}{l}241+30-20 \mathrm{ka}(\mathrm{ESR}) \\
302 \pm 12 \mathrm{ky}(\mathrm{OSL}) 175 \pm 6 \mathrm{ka}(\text { IRSL) }\end{array}$ & $\begin{array}{l}1013 \\
1014(0+0) \\
2852(1+0)\end{array}$ \\
\hline Ribatejo & $\begin{array}{l}\text { Vale do Forno } 3 \text { /Milharós } \\
\text { Vale do Forno } 8\end{array}$ & Tejo T4 fluvial terrace & $\begin{array}{l}119+\infty-32 \mathrm{ka}(\mathrm{TL}) \\
127+\infty-26 \mathrm{ka}(\mathrm{TL})\end{array}$ & $\begin{array}{l}338(24+13) \\
3000(?)\end{array}$ \\
\hline
\end{tabular}



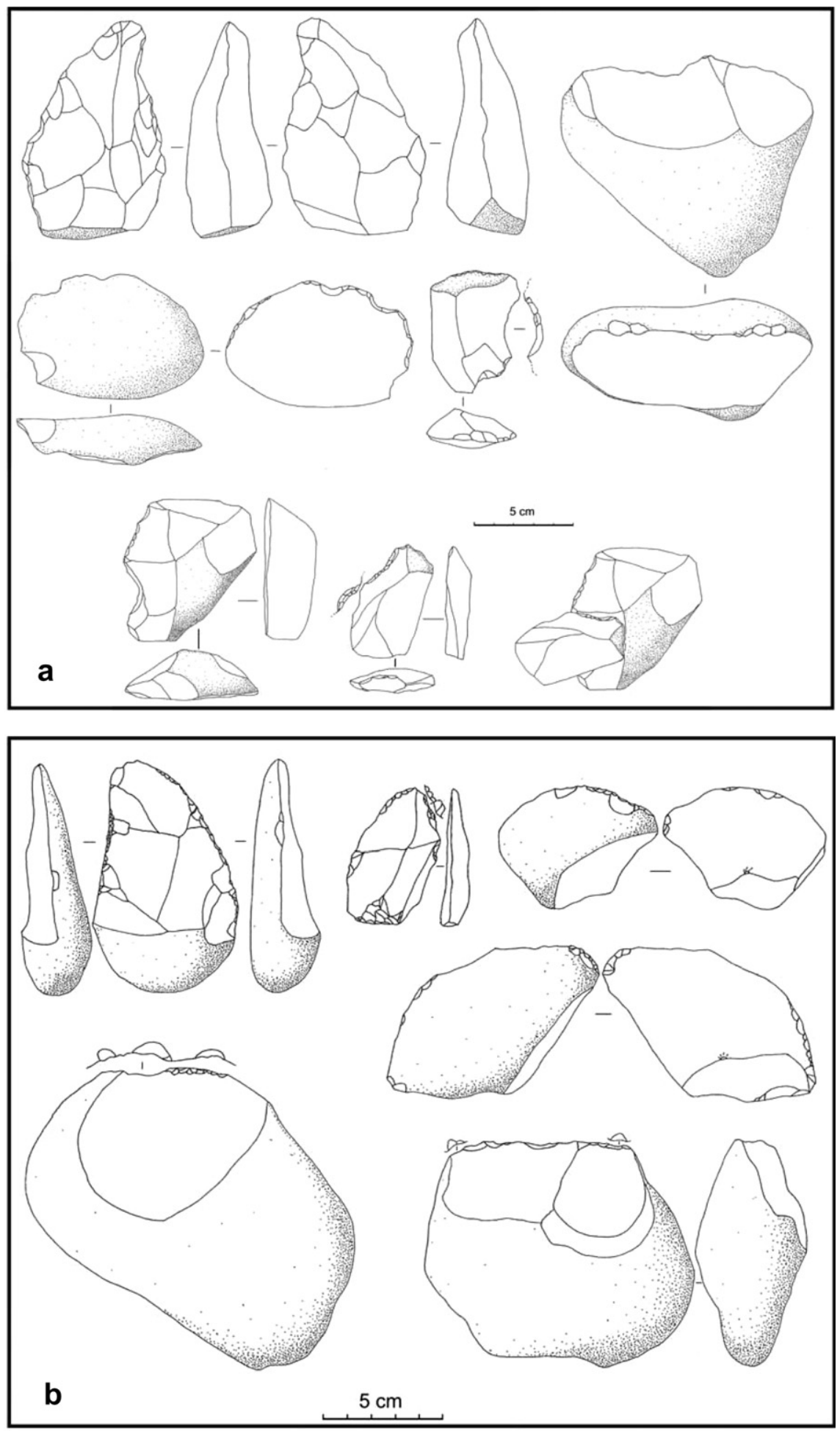

Fig. 5. Lithic implements from the Fonte da Moita (a) and Ribeira da Ponte da Pedra (b) sites (after Grimaldi et al., 1999b, Grimaldi and Rosina, 2001).

numerical ages (e.g. luminescence and U-series dating) and palaeomagnetic studies. However, the chronological framework is a major issue as the range of applications is limited by methodological constraints and spatial coverage is sparse (Santisteban and Schulte, 2007). Knowledge about the evolution of the Tejo fluvial networks has improved during the recent years as more geomorphological, sedimentological, paleontological and geochronological data has become available, especially in central Iberia (e.g. PérezGonzález, 1994; Santonja and Pérez-González, 2000-2001; Gutiérrez-Elorza et al., 2002; Benito et al., 2003; Bridgland et al., 2006; Ortiz et al., 2009).

Similar approaches have been carried out, and are still ongoing, in western Iberia and especially in the Alto Ribatejo region (central Portugal). Here, a developed geoarchaeological perspective shed 
more light into the issue of the earliest human presence in this region (Mozzi et al., 1999; Corral, 1998a, 1998b; Rosina, 2002, 2004; Rosina et al., 2005).

In the Portuguese Tejo River, the aggradational terraces consist mainly of coarse-grained siliciclastic gravels and sands, which are generally unsuitable for the preservation of organic remains due to hydrodynamic and diagenetic processes. Nevertheless, a few dates have been obtained for the T6, T5, and T4 lower terraces (Daveau, 1993; Silva et al., 1997; Raposo and Cardoso, 1998; Martins, 1999; Raposo, 2000; Silva, 2003; Cunha et al., 2005, 2008; Martins et al., 2009, in press-a, in press-b) where the most ancient in situ lithic implements have been found so far.

Table 1 summarizes the main features of the earliest archaeological contexts of western Iberia. With the exception of the controversial date for Alpiarça VF8 site, the only dates available are those for the Ribeira Ponte da Pedra open air site (Martins et al., 2009, in press-b; Dias et al., 2010). Both sites are located in the Tejo middle terrace (T4 terrace in the Portuguese Tejo) that is, according with data coming from central Iberia, chronologically related to a final stage of Middle Pleistocene. Most ancient dates are those from the cave site of Galeria Pesada and from the Monte Famaco site (T4 terrace). All these dates seem to suggest that the most ancient human presence in Central Portugal (and consequently, in western Iberia) should be no older than the MIS 8-9.

Very few studies from a behavioural perspective have been carried out so far (see for an example Grimaldi et al., 1998, 1999a, $1999 \mathrm{~b})$. The first results seem only to scratch the surface of a wider scenario related to the first human presence in this region.

As far as lithic implements are concerned, technological and functional analyses have been carried out only for the Riberia Ponte da Pedra and Fonte da Moita lithic assemblages (Grimaldi et al., 2000; Grimaldi and Rosina, 2001; Lemorini et al., 2001; Cura and Grimaldi, 2009; Cristiani et al., 2010). Other lithic assemblages have been analysed by several scholars mainly by typological observations, with special attention to the presence/absence of "typical" Middle Pleistocene morphologies, notably bifaces (in the sense given to these morphologies by the traditional Acheulean or Micoquian definition) (Oosterbeek et al., in press). Bifaces seem to be absent only at Riberia Ponte da Pedra and Fonte da Moita sites, while they are present in other Ribatejo and Alto Ribatejo sites even if their frequency percentages remain low or very low.

Raw materials do not show relevant variability among sites. Assemblages are made from local quartzite pebbles and boulders, easily collectable everywhere; quartz is also present to a minor extent. Silica is very rare, or absent as in Riberia Ponte da Pedra and Fonte da Moita, but it is more common in Galeria Pesada, where it is locally collectable.

The Alto Ribatejo lithic assemblages share the main technical and morphological characteristics. The overall feature is an archaic aspect defined by three major groups: (a) worked pebbles; (b) non retouched blanks; (c) retouched blanks. These groups can be viewed as the result of a single and technological simple reduction sequence: pebbles have been knapped in order to produce flakes (mainly cortical or half-cortical ones). The reduced number of flake scars can be associated to an "expedient" production of large/ massive blanks and may also indicate a functional need based over quantity, rather than quality of the blanks. More, some of these worked pebbles present features that indicate their utilization as chopping tools (Cristiani et al., 2010).

Formal retouched tools are very rare. Most abundant are blanks characterised by a marginal, coarse retouch not resulting on "classic types" of tools (Fig. 5). These blanks are pebbles (worked or not worked ones) and flakes, mainly on cortical or half-cortical ones. The experimental and functional studies suggest that most of the edges showing this kind of retouch can be attributed to different types of edge-modifications resulting from subsistence activities, mainly corresponding to the use on hard and very hard materials, mainly scraping, probably wood and horn. Dry hide was scraped, and there is also evidence of meat and bone cutting and scraping, representing butchering activities (Lemorini et al., 2001; Cristiani et al., 2010).

\section{Conclusions}

This brief summary of the archaeological evidence for the earliest human presence in western Iberia aims to introduce the results recently obtained from the integration of geomorphological, sedimentological and archaeological approaches, but also numerical dating, carried out by the authors in the Portuguese region of Alto Ribatejo (see Table 1). The first human presence in the region seems to be no older than MIS 8-9, corresponding to lithic assemblages found at the Tejo River T4 middle terrace or in cave deposits. According to the traditional typological framework, the presence of bifacial tools - even if rare or, in some sites, absent relate these lithic assemblages to a middle and/or final Acheulean stage according to morphological differences that several scholars consider as chronological markers. The only sites with no bifacial tools, i.e. Riberia Ponte da Pedra and Fonte da Moita, are characterised by a very "easy-to-produce" technique (which is observed also in the other sites of the region) finalised by the realisation of worked pebbles - in the sense of Choppers and Chopping tools - in order to produce large, cortical flakes. Both pebbles and flakes have been used for multi functional purposes, suggesting a generalised exploitation model of the local natural resources. The lithic assemblages of both Galeria Pesada and VF8 in Alpiarça seem to be an exception to this model thanks to the presence of bifacial implements. Unfortunately, little attention has been paid to the so-called "accompanying" artefacts, i.e. flakes, cores and debris, of these sites. It could be very useful to compare from a technofunctional standpoint the blank categories coming from these sites in order to better evaluate similarities or differences between the "accompanying" industries of sites with bifacial tools and those of sites without bifacial tools.

Although the reported available data are similar to the results obtained from sites in central Iberia, it remains very difficult to explain the chronological gap between this late Middle Pleistocene evidence and the older sites in the Sierra de Atapuerca and Guadix Baxa areas. The lack of palaeoenvironmental data and the paucity of faunal data make it difficult for a detailed reconstruction of the landscape. It could be argued that the large presence of the earliest lithic evidences at the base of the Tejo River middle terrace (T4, in a suite of six terraces) is associated with a rapid increase of the human presence in this region, maybe linked with favourable environmental conditions during the MIS 7-9 interval. New archaeological finds, namely in the karst area and in terrace deposits, and numerical dating of the older terraces may provide a better understanding of the human occupation model of western Iberia.

\section{Acknowledgments}

This work is within the scope of projects PTDC/HAH/71361/2006 and POCI/CTEGEX/58120/2004, approved by the Fundação para a Ciência e a Tecnologia and cofounded by the FEDER. The authors thank the town hall of Vila Nova da Barquinha,. Research was supported by the Polytechnic Institute of Tomar, Archaeology Interpretation Centre of the Alto Ribatejo, Museum of Prehistoric Art in Mação, IMAR-CIC - Univ. Coimbra, Centro de Geociências Univ. Évora, Centro de Geociências - Univ. Coimbra (Research Group "Quaternary and Pre-History”). 


\section{References}

Azevedo, T.M., Cardoso, J.L., Penalva, C., Zbyszewski, G., 1979. Contribuiçao para o conhecimento das industria líticas mais antigas do território português: as jazidas com "Pebble-Culture" da formaçao de Belverde - península de Setúbal (Vilafranquiano medio). Setubal Arqueologica 5, 31-44.

Benito, G., Sopena, A., Sanchez-Moya, Y., Machado, M.J., Perez-Gonzalez, A., 2003. Palaeoflood record of the Tagus River (Central Spain) during the Late Pleistocene and Holocene. Quaternary Science Reviews 22, 1737-1756.

Biberson, P., 1961a. Le cadre paléogéographique de la préhistoire du Maroc atlantique. Service des Antiquités du Maroc, Rabat.

Biberson, P., 1961b. Le Paléolithique inférieur du Maroc atlantique. Service des Antiquités du Maroc, Rabat.

Biberson, P., 1976. Les plus anciennes industries du Maroc. IX Congrès U.I.S.P.P. Nice, pp. $118-39$.

Breuil, H., 1959. Contribution à l'étude des terrasses quaternaires au Portugal. I - La Pebble Culture a Magoito. Trabalhos de Antropologia e Etnologia 17 (1-4), 9-12.

Breuil, H., Zbyszewski, G., 1942. Contribution à l'étude des industries paléolithiques du Portugal et de leurs rapports avec la géologie du Quaternaire. Les principaux gisements des deux rivers de l'ancien estuaire du Tage, vol. XXIII. Com. dos Serv. Geol. de Portugal, Lisboa, 369 p.

Breuil, H., Zbyszewski, G., 1945. Contribution à létude des industries Paléolithiques du Portugal et de leurs rapports avec la géologie du Quaternaire. Les principaux gisements des plages quaternaires du littoral d'Estremadura et des terrasses fluviales de la basse vallée du Tage, vol. XXVI. Com. dos Serv. Geol. de Portugal, Lisboa, $678 \mathrm{p}$

Bridgland, D.R., Antoine, P., Limondin-Lozouet, N., Santisteban, J.I., Westaway, R., White, M.J., 2006. The Palaeolithic occupation of Europe as revealed by evidence from the rivers: data from IGCP 449. Journal of Quaternary Science 21, 437-455.

Cabral, F., 1881. Estudo dos depósitos superficiaes da bacia do Douro. Secção dos Trabalhos Geológicos de Portugal, Lisboa.

Carbonell, A., Bermúdez de Castro, J.M., Parés, J.M., Pérez-González, A., CuencaBescós, G., Ollé, A., Mosquera, M., Huguet, R., van der Made, J., Rosas, A., Sala, R., Vallverdú, J., García, N., Granger, D.E., Martinón-Torres, M., Rodríguez, X.P., Stock, G.M., Josep, M., Vergés, J.M., Allué, E., Burjachs, F., Cáceres, I., Canals, A., Benito, A., Díez, C., Lozano, M., Mateos, A., Navazo, M., Rodríguez, J., Rosell, J., Arsuaga, J.L., 2008. The first hominid of Europe. Nature 452, 465-469.

Cardoso, J.L., Penalva, C., 1979. Vestigios de praia calabriana com industrias da "Pebble Culture" no Alto de Leiao. Boletim da Sociedade Geologica de Portugal 21, 185-195.

Corral, I., 1998a. Depositos Cuaternarios en el área de Constância-BarquinhaEntroncamento y la Rib. del Bezelga. In: Cruz, A.R., Oosterbeek, L., Pena dos Reis, R. (Eds.), Quaternário e Pré-História do Alto Ribatejo. CEIPHAR, Tomar, Portugal, pp. 59-144. Arkeos 4.

Corral, I., 1998b. Secciones com material arqueológico en estrato en las proximidades de Atalaia. In: Cruz, A.R., Oosterbeek, L., Pena dos Reis, R. (Eds.) Quaternário e Pré-História do Alto Ribatejo. CEIPHAR, Tomar, Portugal, pp. 227-250. Arkeos 4.

Cristiani, E., Cura, S., Grimaldi, S., Gomes, J., Oosterbeek, L. Rosina, P., 2010. Functional analysis and experimental archaeology: the Middle Pleistocene site of Ribeira da Atalaia, (Central Portugal). In: Araujo Igreja M., Clemente Conte I. (Eds.), Proceedings of the workshop on "Recent Functional Studies on Non-Flint Stone Tools, Methodological Improvements and Archaeological Inferences", (Lisbon 2008), CD-ROM. ISBN 978-989-20-1803-4. http://www.workshoptraceologia-lisboa2008.com.

Cunha, P.P., Martins, A.A., Daveau, S., Friend, P.F., 2005. Tectonic control of the Tejo river fluvial incision during the late Cenozoic, in Ródão - central Portugal (Atlantic Iberian border). Geomorphology 64, 271-298.

Cunha, P.P., Martins, A.A., Huot, S., Murray, A., Raposo, L., 2008. Dating the Tejo River lower terraces in the Ródão area (Portugal) to assess the role of tectonics and uplift. Geomorphology 102, 43-54.

Cunha-Ribeiro, J.P., 1990. Os primeiros habitantes. In: Alarcão, J. (Ed.), Nova História de Portugal, vol. I, Portugal das Origens à Romanização, coord. Editorial Presença, Lisboa, pp. 15-74.

Cunha-Ribeiro, J.P., 1992-1993. Contribuição para o estudo do Paleolítico do vale do rio Lis no seu contexto crono-estratigráfico. Portugália, Nova Série 13-14, 7-137.

Cunha-Ribeiro, J.P., 1993. O Paleolítico Inferior em Portugal. O Quaternário em Portugal, Balanço e Perspectivas. Edições Colibri, Lisboa, pp. 133-146.

Cunha-Ribeiro, J.P., 1995. Elementos para o estudo da cadeia operatória de produção de bifaces da indústria acheulense do Casal do Azemel. In: Actas do 1 ${ }^{\circ}$ Congresso de Arqueologia Peninsular, vol. 8. Vale do rio Lis, Distrito de Leiria, Centro de Portugal, pp. 51-68

Cunha-Ribeiro, J.P., 1996. The Acheulian of Lis valley. In: Moloney, N., Raposo, L., Santonja, M. (Eds.), Non-flint stone tools and the palaeolithic occupation of the Iberian Peninsula, vol. 649. BAR International Series, pp. 141-146.

Cunha-Ribeiro, J.P., 1996-1997. Os Machados de Mão no Paleolítico Inferior Português. Portugália, Nova Série XVII-XVIII, 23-50.

Cunha-Ribeiro, J.P., 1999. O Acheulense no Centro de Portugal: o Vale do Lis. Contribuição para uma abordagem das suas indústrias líticas e problemática do contexto cronoestratigráfico. PhD thesis, University of Lisbon, 3 vols.

Cunha-Ribeiro, J.P., 2000. A indústria lítica do Casal do Azemel no contexto da evolução do Paleolítico Inferior na Ibéria Ocidental. In: Actas do $3{ }^{\circ}$ Congresso de Arqueologia Peninsular, vol. 2, 137-167.
Cunha-Ribeiro, J.P., 2002. O Paleolítico Inferior em Portugal no final do século XX: balanço das investigações e novos desafios. Revista da Associação dos Arqueólogos Portugueses 54, 13-24.

Cunha-Ribeiro, J.P., 2005. O Paleolítico Inferior - os primeiros habitantes da bacia do rio Lis. In: Carvalho, S. (Ed.), Habitantes e Habitats. Pré e proto-história na Bacia do Lis. Câmara Municipal de Leiria, Leiria.

Cunha-Ribeiro, J.P., Meireles, J., Texier, J.P., 1989. L'Acheulean du nord et du centre du Portugal: bilan de nos connaissances actuelles. Paléo, Supplément $N^{\circ} 1,185-193$

Cura, S., Grimaldi, S., 2009. The intensive quartzite exploitation in Midlle Tagus Valley Pleistocene open air sites - the example of Ribeira da Ponte da Pedra. In: Grimaldi, S., Cura, S. (Eds.), Technological Analysis on Quartzite Exploitation, Proceedings of the XV World Congress UISPP, Lisbon, 4-9 September 2006. BAR International Series. 1998, pp. 49-56.

Daveau, S., 1993. Terraços fluviais e litorais. O Quaternário em Portugal. Balanço e perspectivas. Colibri, Lisboa, pp. 17-28.

Dias M.I, Prudêncio M.I., Franco D., Cura S., Grimaldi S., Oosterbeek L., Rosina P., 2010. Luminescence dating of a fluvial deposit sequence: Ribeira da Ponte da Pedra - Middle Tagus Valley, Portugal. In: M.I. Prudêncio, M.I. Dias (Eds.) Proceedings of the XV World Congress UISPP (Lisbon, 4-9 September 2006) "Archaeometry". Oxford, ArchaeoPress, BAR-International Series 2045.

GEPP, 1977. O estudo do pelolítico da área do Ródão. O Arqueólogo Português, $3^{\mathrm{a}}$ série 7-9, 31-47.

Gracia Prieto, F.J., Giles Pacheco, F., Cano Pan, J.A., Santiago Pérez, A., Mata Almonte, E.Y., Gutiérrez López, J., 2004. Evolución geomorfológica de la cuenca del río Louro en conexión con el valle del Miño y poblamiento paleolítico (Gándaras de Budiño-Tuy; Pontevedra). Volumen IV Arqueología. In: Baquedano, E., Rubio Jara, S. (Eds.), Miscelánea en homenaje a Emiliano Aguirre, vol. 4. Zona Arqueológica, pp. 219-229.

Grimaldi, S., Rosina, P., 2001. O Pleistoceno Médio Final no Alto Ribatejo (Portugal central): o sítio da Ribeira da Ponte da Pedra. In: Cruz, A.R., Oosterbeek, L. (Eds.), Territórios, mobilidade e povoamento no Alto-Ribatejo. II: Santa Cita e o quaternário da região. CEIPHAR, Tomar, pp. 89-116. Arkeos 11.

Grimaldi, S., Rosina, P., Corral, I., 1998. Interpretazione Geo-Archeologica di alcune industrie litiche "Languedocensi" del Medio Bacino del Tejo. In: Quaternário e Pré-História do Alto Ribatejo (Portugal). CEIPHAR, Tomar, pp. 145-226. Arkeos 4.

Grimaldi, S., Rosina, P., Cruz, A.R., Oosterbeek, L., 1999a. A geo-archaeological interpretation of some "Languedocian" lithic collections of the Alto Ribatejo (Central Portugal). In: Cruz, A.R. (Ed.), Human Population Origins in the CircumMediterranean Area. CEIPHAR, Tomar, pp. 231-241. Arkeos 5.

Grimaldi, S., Rosina, P., Boton Garcia, F., 1999b. A behavioral perspective on "archaic" lithic morphologies in Portugal: the case of Fonte da Moita open air site. Journal of Iberian Archaeology 1, 33-57.

Grimaldi, S., Rosina, P., Boton, F., 2000. Um sítio ao ar livre do Plistoceno Médio no Alto Ribatejo (Portugal): Fonte da Moita. In: Proceedings $3{ }^{\circ}$ Congresso de Arqueologia Peninsular, Porto, vol. 2. ADECAP, pp. 123-131.

Gutiérrez-Elorza, M., García-Ruiz, J.M., Goy, J.L., Gracia, F.J., Gutiérrez-Santolalla, F., Martí, C., Martín-Serrano, A., Pérez-González, A., Zazo, C., Aguirre, E. 2002. Quaternary. In: Gibbons, W., Moreno, T. (Eds.), The Geology of Spain. The Geological Society, pp. 335-366.

Lemorini, C., Grimaldi, S., Rosina, P., 2001. Observações funcionais e tecnológicas num habitat Paleolítico: Fonte da Moita (Portugal central). In: Cruz, A.R. Oosterbeek, L. (Eds.), Territórios, mobilidade e povoamento no Alto-Ribatejo. II: Santa Cita e o Quaternário da região. CEIPHAR, Tomar, pp. 117-140. Arkeos 11.

Marks, A.E., Monigal, K., Chabai, V., 1999. Report on the initial excavations of Brecha das Lascas and Galeria Pesada (Almonda, Portuguese Estremadura). Journal of Iberian Archaeology 1, 237-250.

Marks, A.E., Brugal, J.Ph., Chabai, V.P., Monigal, K., Goldeberg, P., Hockett, B. Pemán, E., Elorza, M., Mallol, C., 2002a. Le gisement Plèistocène moyen de Galeria Pesada, (Estrémadure, Portugal). premiers résultats. Paléo 14, 77-100.

Marks, A.E., Monigal, K., Chabai, V.P., Brugal, J.Ph., Goldeberg, P., Hockett, B. Pemán, E., Elorza, M., Mallol, C., 2002b. Excavations at the Middle Pleistocene Cave Site of Galeria Pesada, Portuguese Estremadura: 1997-1999. O Arqueólogo Português, Série IV 20, 7-38.

Marks, A.E., 2005. Micoquian Elements in the Portuguese Middle Pleistocene Assemblages from the Galeria Pesada. In: Ferreira Bicho, N. (Ed.), O Paleolítico: Actas do IV Congresso de Arqueologia Peninsular, Centro de Estudos de Património. Universidade do Algarve, pp. 195-200.

Martins, A. A., 1999. NonEnCaracterização morfotectónica e morfossedimentar da Bacia do Baixo Tejo (Pliocénico e Quaternário). PhD. Thesis, Univ. Évora, Portugal, 500 p.

Martins, A.A., Cunha, P.P., Huot, S., Murray, A., Buylaert, J., 2009. Geomorphological correlation of the tectonically displaced Tejo river terraces (Gavião-Chamusca area, Portugal) supported by luminescence dating. Quaternary International 199, 75-91.

Martins, A. A., Cunha, P. P., Rosina, P., Oosterbeek, L., Cura, S., Grimaldi, S., Gomes, J. Buylaert, J. -P., Murray, A. S., Matos, J. in press-a Geoarcheology of Pleistocene open-air sites in the Vila Nova da Barquinha - Santa Cita area (lower Tejo rive basin, central Portugal). Proceedings of the Geologists' Association, Elsevier Science Publishers. PGEOLA-D-09-00024, in press.

Martins, A. A., Cunha, P. P., Buylaert, J. -P., Huot, S, Murray, A. S., Dinis, P., Stokes, M K-Feldspar IRSL dating of a Pleistocene river terrace staircase sequence of the Lower Tejo River (Portugal, western Iberia). Quaternary Geochronology, doi: 10.1016/j.quageo.2009.06.004, Reference: QUAGEO 226, in press. 
Meireles, J., 1992. As indústrias líticas do litoral minhoto. Contexto cronoestratigráfico e paleoambiental. Cadernos de Arqueologia. Monografias 7, 577.

Meireles, J., 1994. As indústrias líticas pré-históricas do Litoral do Minho (Portugal) Actas do 1 Congresso de Arqueologia Peninsular 4, 17-42.

Méndez Quintas, E., Villar Quinteiro, R., Santonja Gómez, M., Pérez-González, A. Ledo Bernárdez, M., 2006. Miscelánea en homenaje a Victoria Cabrera. Zona Arqueológica 7, 184-193.

Mozzi, P., Raposo, L., Cruz, A., Oosterbeek, L., Reis, R., 1999. Morpho-stratigraphy of Quaternary deposits and the archaeological record: the case of the Tejo and Nabão valleys (Ribatejo, Portugal). In: Cruz, A.R., Milliken, S., Oosterbeek, L., Peretto, C. (Eds.), Human Population Origins in the Circum Mediterranean Area: Adaptations of the Hunter-Gatherer Groups to Environmental Modifications. CEIPHAR, Tomar, pp. 63-84. Arkeos 5.

Mozzi, P., Azevedo, T., Nunes, E., Raposo, L., 2000. Middle terrace deposits of the Tagus river in Alpiarça, Portugal, in relation to early human occupation. Quaternary Research 54, 359-371.

Oosterbeek, L., Cura, S., Rosina, P., Grimaldi, S., Cruz, A., Gomes, J., Un cadre géochronologique et stratégies de gestion du territoire des cultures du Pléistocène Inférieur et Moyen dans la vallée du Tage (Portugal) L'Anthropologie, in press.

Ortiz, J.E., Torres, T., Delgado, A., Reyesb, E., Díaz-Bautista, A., 2009. A review of the Tagus river tufa deposits (central Spain): age and palaeoenvironmental record. Quaternary Science Reviews 28, 947-963.

Penalva, C., 1978. Ensaio de correlação do fácies Lusitaniano com as industrias do Marrocos atlântico. Comunicações dos Serviços Geológicos de Portugal 63, 521-546.

Penalva, C., 1980. Vestígios de ocupação mustirense na praia tirreniana da S.Juliao (Ericeira). Arqueologia vol. 2, 3-7.

Peréz-Gonzalez, A., 1994. Depresión del Tajo. In: Elorza, G.M. (Ed.), Geomorfología de España. Editorial Rueda, Madrid, 526 pp.

Querol, M.A., Santonja, M., 1983. El yacimiento de cantos trabajados de El Aculadero (Puerto da Santa Maria, Cádiz). Excavaciones Arqueológicas en España 130. Ministerio de Cultura, Madrid.

Raposo, L., 1985. Le Paleolithique inferieur archaique au Portugal: bilan dês connaissances. Bull. de la Societé Préhistorique Francaise 82 (6), 173-182.

Raposo, L., 1987. Os mais antigos vestígios de ocupação humana paleolítica na região de Ródão. Da Pré-História à História, homenagem a O. Editorial Delta, Veiga Ferreira. 153-178.

Raposo, L., 1993. O Paleolítico. In: Medina, J. (Ed.), História de Portugal. Dos tempos pré-históricos aos nossos dias. Alfragide, Ediclube, pp. 39-111.

Raposo, L., 2000. The middle-upper Palaeolithic transition in Portugal. In: Stringer, C., Barton, R.N.E., Finlayson, C. (Eds.), Neanderthals on the Edge: 150th Anniversary Conference of the Forbes' Quarry Discovery, Gibraltar. Oxbow Books, Oxford, pp. 95-109.

Raposo, L., 2002. Bifaces e machados em quartzito na indústria acheulense final de Milharós (Alpiarça), vol. 1. Arqueologia, História de Arte e Património, Revista Lusíada. 9-29.

Raposo, L., Carreira, J.R., 1986. Acerca da existência de complexos industriais préacheulenses no território português. O Arqueólogo Português 4, 7-90.

Raposo, L., Santonja, M., 1996. The earliest occupation of Europe: the Iberian Peninsula. In: Roebroeks, W., van Kolfschoten, T. (Eds.), The earliest occupation of Europe. University of Leiden, pp. 7-25.

Raposo, L., Cardoso, J.L., 1998. O Sítio do Paleolítico Médio da Conceição (Alcochete), vol. 74. Centro de Estudos e Monitorização Ambiental.

Raposo, L., Carreira, J.R., Salvador, M., 1985. A estação Acheulense final de Milharós, Vale do Forno, Alpiarça, vol. 2. I Reunião do Quaternário Ibérico (Proceedings), Lisboa. 79-90.
Raposo, L., Salvador, M., Pereira, J.P., 1993. O Acheulense no Vale do Tejo, em território português. Arqueologia \& História, Série X 3, 3-29.

Ribeiro, C., 1871. Descrição de alguns sílex e quartzites lascados encontrados em camadas dos terrenos terciário e quaternário das bacias do Tejo e Sado. Typ. da Academia 57.

Ribeiro, O., 1943. Novas observações geológicas e morfológicas nos arredores de Vila Velha de Ródão. Publicações do Museu e Laboratório Mineralógico e Geológico da Faculdade de Ciências do Porto 32, 1-24.

Rosina, P. 2002. Stratigraphie et géomorphologie des terrasses fluviatiles de la moyenne Vallée du Tage (Haut Ribatejo, Portugal). In: Cruz, A.R., Oosterbeek, L. (Eds.), Territórios, mobilidade e povoamento no Alto-Ribatejo, vol. IV. Contextos macrolíticos, pp. 11-52. Arkeos 13.

Rosina, P. 2004. I depositi quaternari nella Media Valle del Tago (Alto Ribatejo, Portogallo centrale) e le industrie litiche associate. Thèse de Doctorat soutenue auprès de l'Université de Ferrara, $204 \mathrm{p}$.

Rosina, P., Oosterbeek, L., Jaime, A., Cura, S., 2005. Archaeological sites associated with Tagus Middle Valley deposits (Alto Ribatejo - Portugal). In: Santoja, M. Pérez-Gonzales, A., Machado, M.J. (Eds.), Geoarqueologia y Patrimonio en la peninsula ibérica y el entorno Mediterraneo, pp. 273-282.

Santonja, M., Pérez-González, A., 2000-2001. El Paleolítico inferior en el interior de la Península Ibérica. Un punto de vista desde la geoarqueología. Zephyrus 53-54, 27-77.

Santisteban, J., Schulte, L., 2007. Fluvial networks of the Iberian Peninsula: a chronological framework. Quaternary Science Reviews 26, 2738-2757.

Serpa Pinto, R., 1932. Nota para um plano de estudos geológicos entre o Minho e o Lima. Anuário do Distrito de Viana do Castelo 1, 27-88.

Silva, P.G., 2003. El Cuaternario del valle inferior del Manzanares (Cuenca de Madrid, España). Estudios Geológico 59, 107-131.

Silva, P.G., Cañaveras, J.C., Zazo, C., Sánchez-Moral, S., Lario, J., Sanz, E., 1997. 3D softsediment deformation structures: existence for Quaternary seismicity in the Madrid basin. Spain. Terra Nova 9, 208-212.

Texier, J.P., Meireles, J., 1987. As formações quaternárias do litoral do Minho (Portugal): propostas para uma nova abordagem climato-cronológica e dinâmica. Cadernos de Arqueologia 4, 9-33.

Trinkaus, E., Marks, A.E., Brugal, J.-P., Bailey, S.E., Rink, W.J., Richter, D., 2003. Later Middle Pleistocene human remains from the Almonda Karst system, Torres Novas, Portugal. Journal of Human Evolution 45, 219-226.

Zbyszewski, G., 1943. La classification du Paléolithique ancien et la chronologie du Quaternaire de Portugal en 1942. Boletim da Sociedade Geológica de Portugal 2 (2-3), 111.

Zbyszewski, G., 1946. Étude géologique de la region d'Alpiarça. Comunicações dos Serviços Geológicos de Portugal XXVII, 145-268.

Zbyszewski, G., 1953. Carta Geológica de Portugal na escala 1:50 000, Notícia Explicativa da Folha 31-A Santarém. Serviços Geológicos de Portugal, Lisboa, 16 p.

Zbyszewski, G., 1958. Le Quaternaire du Portugal. Boletim da Sociedade Geológica de Portugal 12, 1-227.

Zbyszewski, G., Ferreira, O., Penalva, C., 1979. A "Pebble Culture" do litoral, entre Laredo das Corchas e a Ponta Ruiva (Algarve), nota preliminar. Setubal Arqueologica 5, 17-26.

Zbyszewski, G., Ferreira, O., Penalva, C., 1981. Nota prévia sobre a "Pebble Culture" da praia calabriana do Mirouço (Algarve). Madrider Mitteilungen 22, 11-18.

Zbyszewski, G., Penalva, C., Ferreira, O.V., Leitão, M., North, C.T., 1982. A "Pebble Culture" do nivel Calabriano de Seixosa (Portugal). Aspectos tipologicos e geologicos. Memorias da Academia das Ciencias de Lisboa 24, 127-162. 